\title{
VOTING POWER INDICATORS IN THE EUROPEAN UNION
}

\author{
Marek LOUŽEK*
}

\begin{abstract}
:
The article is concerned with voting power indicators in the European Union and one paradox arising from them. The first chapter defines voting power indicators exactly. The second chapter defines the paradox of new members and introduces some examples. The third chapter specifies data - voting power indicators in the EU. The fourth chapter computes differences between old and new voting power indicators. The fifth chapter summarizes the frequency of the paradox of new members in total. The sixth chapter brings a conclusion.
\end{abstract}

Keywords: voting indicator, EU enlargement, index of power, minimal winning coalitions, game theory, quantitative analysis

JEL Classification: C43, C12

\section{Voting Power Indicators}

One of the most interesting problems in the public choice theory, which stands on the confines of economics and political science, is the paradox of new members. The paradox of new members says that a voting power of a member, during the enlargement of a community, doesn't have to decrease significantly, but it can even increase. The aim of this paper is to quantify voting power indicators in the enlarged European Union and test whether the paradox of new members came into being in May 2004.

At first, I define voting power indicators and the paradox of new members. Then I describe data - voting power indicators in the EU. There are computed differences between old and new voting power indicators and summarized the frequency of the paradox of new members in total. I find out that the paradox of new members appears during the EU enlargement relatively often, although not all hypotheses connected with the paradox in traditional literature are confirmed.

Voting power indicators are ways of mathematical measuring of voting power in political bodies. Linking up to Banzhaf (1965), Coleman (1971), Brams (1976), Taylor (1995), Machover and Felsenthal (1998), Turnovec (2000) and Loužek (2004), I distinguish four voting power indicators: A. simple relative power, B. share in majority coalitions, C. Banzhaf index and D. Coleman index.

*) Center for Economics and Politics, Politických vězňů 10, CZ - 11000 Prague 1 and University of Economics, 4, W. Churchill Sq., CZ - 13067 Prague 3 (e-mail: louzek@ post.cz). 
A. Simple Relative Power is defined as $R_{i}=\frac{v_{i}}{\sum_{i=1}^{n} v_{i}}$, where the numerator means the number of votes, which a member of the community has, and the denominator means the total number of all votes. Let's use an example where the voters are $p_{1}$, $p_{2}$ and $p_{3} ; p_{1}$ has fifty votes, $p_{2}$ has forty-nine votes, $p_{3}$ has one vote. Then the simple relative power of individual members is

$R\left(p_{1}\right)=50 / 100=0.50$

$R\left(p_{2}\right)=49 / 100=0.49$

$R\left(p_{3}\right)=1 / 100=0.01$

This voting power indicator seems to be advantageous, because of computing simply and elegantly the voting power according to the number of votes. A problem is that the simple relative power takes only the nominal number of votes into account, not the real share in winning coalitions. Some members can be dummies and the relative power can differ from a participation of members on different voting combinations. Therefore, other voting power indices have been developed.

Taylor (1995) introduces Shapley-Shubik index of a player $p_{i}$. The Shapley-Shubik index is the number between zero and one that represents the fraction of orderings for which $p_{i}$ is the pivotal player. We don't use this index because it computes the potential orderings as variations, not combinations of elements, which is unsuitable for analysing practical political life. In real voting behavior, namely, it is not important whether a player is in a variation "ahead" or "behind".

B. Share in Majority Coalitions can be written as $S M=\frac{M C_{i}}{M C}$, where $M C_{i}$ is the number of majority coalitions on which the member $p_{i}$ participates, and $M C$ is the number of all majority coalitions. The coalition is a combination of elements. Let's use the example where the voters are $p_{1}, p_{2}$ and $p_{3} ; p_{1}$ has fifty votes, $p_{2}$ has fortynine votes, $p_{3}$ has one vote. Fifty-one votes are needed for passage. The three majority coalitions are $C_{1}=\left(p_{1}, p_{2}, p_{3}\right), C_{2}=\left(p_{1}, p_{2}\right), C_{3}=\left(p_{1}, p_{3}\right)$. If the first member participates on three coalitions, the second one in two and the third one in one, then

$S M\left(p_{1}\right)=3 / 3$

$S M\left(p_{2}\right)=2 / 3$

$S M\left(p_{3}\right)=1 / 3$

If all members were equally strong, the share of all members in majority coalitions would be $50 \%$. There is the same probability that a concrete member is in a coalition or not. If the power of members is different, the share in majority coalitions would be higher than $50 \%$, according to whether a member in question is strong or weak.

A disadvantage of this index is that a part of majority coalitions is "superfluous", which could stretch the statistics: strong members have bias toward creating a coalition consisting of relatively few members with the aim to decrease the transaction costs. Therefore, the Banzhaf and Coleman index have been developed.

C. Banzhaf index was introduced by the attorney John F. Banzhaf (see Banzhaf, 1965). Suppose that $p_{i}$ is a voter in a yes-no voting system. Then the total Banzhaf 
power of $p_{i}$, denoted here by $B P\left(p_{i}\right)$, is the number of coalitions $C$ satisfying the following three conditions: $p_{i}$ is a member of $C ; C$ is a winning coalition; if $p_{i}$ is deleted from $C$, the resulting coalition is not a winning one. Then the Banzhaf index of $p_{i}$, denoted here by $B I\left(p_{i}\right)$, is the number given by

$$
B I\left(p_{i}\right)=\frac{B P_{i}}{B P_{1}+\ldots+B P_{n}}=\frac{B P_{i}}{\sum_{i=1}^{n} B P_{i}}
$$

Let's use the example where the voters are $p_{1}, p_{2}$ and $p_{3} ; p_{1}$ has fifty votes, $p_{2}$ has forty-nine votes, $p_{3}$ has one vote. Fifty-one votes are needed for passage. The winning coalitions are $C_{1}=\left(p_{1}, p_{2}, p_{3}\right), C_{2}=\left(p_{1}, p_{2}\right), C_{3}=\left(p_{1}, p_{3}\right)$. Total Banzhaf powers are $B P\left(p_{1}\right)=3, B P\left(p_{2}\right)=1, B P\left(p_{3}\right)=1$. Therefore, Banzhaf indices in a 3member voting body are

$B I\left(p_{1}\right)=3 /(3+1+1)=3 / 5$

$B I\left(p_{2}\right)=3 /(3+1+1)=3 / 5$

$B I\left(p_{3}\right)=1 /(3+1+1)=1 / 5$

D. Coleman index as an alternative measure of voting power, Coleman considers a member's voting power to be linked to its ability to prevent the passage of a motion. Like Banzhaf, he relates this ability to a member's critical defections. Unlike Banzhaf, however, Coleman chooses the number of minimal winning coalitions - not the number of critical defections of all members - as its basis of comparison and defines a member's voting power to be the proportion of minimal winning coalitions in which his defection is critical.

Minimal winning coalitions $(M W C)$ are coalitions satisfying the three conditions: $p_{i}$ is a member of winning coalitions; $p_{i}$ is "the biggest" member in the coalition; if $p_{i}$ is deleted from the winning coalition, the coalition ceases to be winning. Suppose that $p_{i}$ is a player in a yes-no voting system. Then the Coleman index of $p_{i}$, denoted here by $C l\left(p_{i}\right)$, is given by $C l\left(p_{i}\right)=\frac{B M_{i}}{M W C}$, where $B M_{i}$ is the Banzhaf power and $M W C$ is the number of minimal winning coalitions.

Let's again use the example where the voters are $p_{1}, p_{2}$ and $p_{3} ; p_{1}$ has fifty votes, $p_{2}$ has forty-nine votes, $p_{3}$ has one vote. The winning coalitions are $C_{1}=\left(p_{1}, p_{2}\right.$, $\left.p_{3}\right), C_{2}=\left(p_{1}, p_{2}\right), C_{3}=\left(p_{1}, p_{3}\right)$. Coleman indices in a 3-member voting body are $C l\left(p_{1}\right)=3 / 3=1$

$C l\left(p_{2}\right)=1 / 3=1 / 3$

$C l\left(p_{3}\right)=1 / 3=1 / 3$

It is apparent that the power values of members given by the Coleman index are simply double the values given by the Banzhaf index. In general, since the numerators of the fractional values for each index are the same, the proportion (or percentage) of the total power held by each member will be the same. However, the Coleman power values for members of a voting body will not in general sum to 1 (or any other constant) but will depend on the composition and decision rule of the body. 
Although both indices are based on the same idea - the ability of members to cast critical votes and thereby block action through their defection from minimal winning coalitions - they summarize information about this ability in different ways. The Banzhaf index, whose component power values for all members of a voting power always sum to 1, highlights the relative amount of voting power possessed by members of different voting bodies. The Coleman index, by contrast, does not highlight a member's share of the total power but emphasizes its absolute ability to block or prevent action by its defection.

In effect, the Banzhaf index assumes a constant-sum game - voting power can only be redistributed (by a change in the decision rule or member weights), whereas the Coleman index assumes a variable-sum game in which everybody's power may go up or down simultaneously. Despite the different conceptualizations of power embodied in each index, they both show up the same paradoxical feature of voting power.

\section{Paradox of New Members}

\section{1 A Definition}

The paradox of new members is defined here in accordance with the traditional literature (see Brams, 1976; Taylor, 1995; Machover and Felsenthal, 1997). Let $I_{k}$ and $I_{j}$ are voting power indicators before and since the enlargement of a community. The paradox of new members comes into being, if $\Delta I>0$, e.g. $I_{k}-I_{j}>0$. Voting power indicators, according to which we find out the paradox, are the following: the simple relative power $(R)$, the share in majority coalitions $(S M)$, the Banzhaf index $(B I)$ and the Coleman index $(C l)$. We ask the question whether

$\Delta R=R_{k}-R_{j}>0$,

$\Delta S M=M C_{k}-M C_{j}>0$,

$\Delta B I=B I_{k}-B I_{j}>0$,

$\Delta C l=C l_{k}-C l_{j}>0$.

A "clear" paradox of new members comes into being, if $\Delta />0$ and no change of decision rule occurs. An "unclear" paradox of new members comes into being, if $\Delta I>0$, while a change of voting rule occurs. If otherwise not stated, we are concerned with the clear paradox of new members in the following section. At first, I want to analyse some exact patterns.

The paradox of new members according to simple relative power $(R)$ cannot come into being, e.g. $R_{k i}<R_{j i}$ is operative for all $i$, where $R_{k i}$ is the relative power of $i$-member after the enlargement of a community and $R_{j i}$ is the relative power of

$i$-member before the enlargement. According to our definition, $R_{i}=\frac{v_{i}}{\sum_{i=1}^{n} v_{i}}$. The en-

largement of the community means that the number of members is not $n$, but $n+m$, where $n$ and $m$ are natural numbers. The sum of votes in the previous community makes $\sum_{i=1}^{n} v_{i}$, the sum of votes of the enlarged community makes $\sum_{i=1}^{n+m} v_{i}$. Therefore, 
I can write $\frac{v_{i}}{\sum_{i=1}^{n+m} v_{i}}<\frac{v_{i}}{\sum_{i=1}^{n} v_{i}}$. Since the numerator and denominator are positive numbers, it is possible to rewrite this unequation to $\sum_{i=1}^{n+m} v_{i}>\sum_{i=1}^{n} v_{i}$, which holds always, if $v_{i}$ are positive numbers.

For the share of countries in majority coalitions (SM), it is not possible to rule out the paradox of new members, e.g. $S M_{k i}>S M_{j i}$, where $S M_{k i}$ is a share of $i$-member in majority coalitions after the enlargement of a community and $S M_{j i}$ is a share of $i$-member in majority coalitions before the enlargement.

According to definition, $S M=\frac{M C_{i}}{M C}$, where $M C_{i}$ is the number of majority coalitions, on which the $i$-member participates, and $M C$ is the number of all majority coalitions. After substituting, we get $\frac{M C_{k i}}{M C_{k}(n+m)}>\frac{M C_{j i}}{M C_{j}(n)}$, where $M C_{k}(n+m)$ is the number of majority coalitions composed of $n+m$ elements, while $M C_{j}(n)$ is the number of majority coalitions composed of $n$ elements. After adjustment

$$
\frac{M C_{k i}}{M C_{j i}}>\frac{M C_{k}(n+m)}{M C_{j}(n)}
$$

I assume that the number of majority coalitions composed of $n$ or $n+m$ elements is a function of the number of combinations composed of $n$, optionally $n+m$ elements. Then it is possible to write

$$
\frac{M C_{k i}}{M C_{j i}}>\frac{f[K(n+m)]}{g[K(n)]}=\frac{f\left[\sum_{k=1}^{n+m} \frac{(n+m) !}{(n+m-k) ! \cdot k !}\right]}{g\left[\sum_{k=1}^{n} \frac{n !}{(n-k) ! \cdot k !}\right]}
$$

Now I assume that the share of majority coalitions in which member $i$ is participating after enlargement is $a^{m}$-times bigger than one before the enlargement (left side of the unequation). At the same time, I assume that the total number of combinations of elements after enlargement of the community is $b^{m}$-times bigger than before the enlargement. If $a$ and $b$ are real positive numbers, it is possible to write $a^{m}>b^{m}$, where $m$ is the number of new members, that is a natural number. After extraction we get $a>b$. Generally there can come into being a situation $a=b$. If this happens, the share in majority coalitions would not change during the enlargement. A "normal" situation is, when $b>a$, e.g. the number of combinations increases faster than the number of majority coalitions. If the number of combinations increases more slowly, that is $a>b$, the paradox of new members arises.

For the Banzhaf index $(B I)$ it is not possible to rule out the paradox of new mem-

bers. According to definition, $B I\left(p_{i}\right)=\frac{B M_{i}}{\sum_{i=1}^{n} B M_{i}}$. The paradox of new members me- 
ans that $B I_{k i}>B I_{j i}$, where $B I_{k i}$ is Banzhaf index of $i$-member after enlargement of the community and $B I_{j i}$ is Banzhaf index of $i$-member before the enlargement. After sub-

stituting $\frac{B M_{k i}}{\sum_{i=1}^{m+n} B M_{i}}>\frac{B M_{j i}}{\sum_{i=1}^{n} B M_{i}}$. After adjustment we get $\frac{B M_{k i}}{B M_{j i}}>\frac{\sum_{i=1}^{n+m} B M_{i}}{\sum_{i=1}^{n} B M_{i}}$.

I assume that the sum of Banzhaf powers increases after enlargement $b^{m}$-times, where $m$ is the number of new members of the community and $b>1$. Let the Banzhaf power of a member after enlargement is $a^{m}$-times bigger than before the enlargement. Then it is possible to write $a^{m}>b^{m}$. If $m \in N$, it is possible to adapt the equation to $a>b$. Generally one cannot rule out the situation $a=b$. In such case, Banzhaf index would not change after the enlargement. The situation $b>a$ is more often, e.g. the sum of Banzhaf powers in the enlarged community increases faster than the Banzhaf power for concrete country. The situation $a>b$ means the paradox of new members.

For the Coleman index $(C /)$ also, one can't rule out the paradox of new members. According to definition, $C I_{i}=\frac{B M_{i}}{M W C}$. The paradox of new members means that $C l_{k i}>C l_{j i}$, where $C l_{k i}$ is the Coleman index of a member after enlargement and $C l_{j i}$ is the Coleman index before the enlargement. After substituting $\frac{B M_{k i}}{M V K_{k}}>\frac{B M_{j i}}{M V K_{j}}$. After adapting we get $\frac{B M_{k i}}{B M_{j i}}>\frac{M V K_{k}}{M V K_{j}}$.

I assume that the number of minimal winning coalitions (MWC) after the enlargement of the community is $b^{m}$-times bigger than the number of $M W C$ before the enlargement, e.g. $b>1$ and $m \in N$. At the same time, Banzhaf index of a member is after enlargement $a^{m}$-times bigger than before enlargement. Then it is possible to write $a^{m}>b^{m}$. If $m \in N$, there must be operative $a>b$. If $a=b$, then Coleman index does not change during the enlargement of the community. The situation $b>a$ is more probable, e.g. the number of $M W C$ increases in an enlarged community faster than Banzhaf power of a concrete country. The situation $a>b$ would be the clear paradox of new members.

\section{2 A Theoretical Example}

Consider a 3-member voting body with weights $(3,2,2)$, in which the decision rule is a simple majority of 4 out of 7 members. There are three distinct minimal winning coalitions $-\left(3,2_{1}\right),\left(3,2_{2}\right)$ and $\left(2_{1}, 2_{2}\right)$ - whose members overlap but are not all identical with those of any other such coalition. Clearly, the subtraction of the 3 -vote member from $\left(3,2_{1}\right)$ and $\left(3,2_{2}\right)$, the $2_{1}$-vote member from $\left(3,2_{1}\right)$ and $\left(2_{1}, 2_{2}\right)$, and $2_{2}$-member from $\left(3,2_{2}\right)$ and $\left(2_{1}, 2_{2}\right)$ would render each minimal winning coalition losing. Altogether, therefore, there are six critical defections for three members of the voting body.

Since each member's defection is critical in two minimal winning coalitions, each member's proportion of voting power is $2 / 6=1 / 3$ by Banzhaf's definition. Since each member's defection in the voting body $(3,2,2)$ is critical in two of the three minimal 
winning coalitions, each member's power to prevent action is $2 / 3$ by Coleman's measure of voting power. If a new 1 -vote member is added to this body so that is becomes $(3,2,2,1)$, how does this increase in the size of the body affect the voting power of the original members, given a decision rule of simple majority (now 5 out of 8$)$ ?

In the enlarged voting body, there are six minimal winning coalitions: $\left(3,2_{1}\right),(3$, $\left.\left.2_{2}\right),\left(3,2_{1}, 1\right),\left(3,2_{2}, 1\right)\right),\left(3,2_{1}, 2_{2}\right),\left(2_{1}, 2,1\right)$. The defection of the 3 -vote member is critical in five coalitions, each of the 2-vote members in two, and the 1-vote member in one, making for a total of twelve critical defections. The Banzhaf power values for the body $(3,2,2,1)$ are, therefore, $(5 / 12,3 / 12,3 / 12,1 / 12)=(5 / 12,1 / 4,1 / 4,1 / 12)$, and the Coleman power values are $(5 / 6,3 / 6,3 / 6,1 / 6)=(5 / 6,1 / 2,1 / 2,1 / 6)$. For a coalition to be considered minimal winning, we require that it be so with respect to the defection of at least one of - but not necessarily all - its members.

While the power of the 2-vote members decreases in the enlarged voting body, the 3-vote member surprisingly increases its power in this body. Specifically, its power increases from $1 / 3=0.33$ to $5 / 12=0.42$ by the Banzhaf index, and from $2 / 3=0.67$ to $5 / 6=0.83$ by the Coleman index - despite the fact that its proportion of votes decreases from $3 / 7=0.43$ in the original body to $3 / 8=0.375$ in the enlarged body. On the basis of this redistribution of power caused by the addition of the 1 -vote member to the original voting body, it seems reasonable to suppose that the 3-vote member would favour an expansion in the size of the voting body by one 1 -vote member!

Table 1

Paradox of New Members in Body $(3,2,2,1)$

\begin{tabular}{|c|c|c|c|c|c|c|c|c|}
\hline \multirow{4}{*}{$\begin{array}{l}\text { Vote } \\
\text { weight }\end{array}$} & \multicolumn{8}{|c|}{ Decision Rule } \\
\hline & \multicolumn{4}{|c|}{ Simple Majority } & \multicolumn{4}{|c|}{ Constant Majority (5 votes) } \\
\hline & \multicolumn{2}{|c|}{ Banzhaf index } & \multicolumn{2}{|c|}{ Coleman index } & \multicolumn{2}{|c|}{ Banzhaf index } & \multicolumn{2}{|c|}{ Coleman index } \\
\hline & Original & Enlarged & Original & Enlarged & Original & Enlarged & Original & Enlarged \\
\hline 3 & 0.33 & 0.43 & 0.67 & 0.83 & 0.60 & 0.42 & 1.00 & 0.83 \\
\hline 2 & 0.33 & 0.25 & 0.67 & 0.50 & 0.20 & 0.25 & 0.33 & 0.50 \\
\hline 2 & 0.33 & 0.25 & 0.67 & 0.50 & 0.20 & 0.25 & 0.33 & 0.50 \\
\hline 1 & - & 0.08 & - & 0.17 & - & 0.08 & - & 0.17 \\
\hline Total & 1.00 & 1.00 & 2.00 & 2.00 & 1.00 & 1.00 & 1.67 & 2.00 \\
\hline
\end{tabular}

Source: Brams (1976).

A member's greater power in the enlarged (versus the original) voting body is an artefact of a change in the decision rule ( 4 out of 7 ) in the original body to 5 out 8 in the enlarged body. What would be the power of the three original members if they operated under a decision rule of 5 out of 7 ? Then the defection of each of the two 2 -vote members $\left(2\right.$ and $\left.2_{2}\right)$ would be critical in one coalition apiece - $\left(3,2_{1}\right)$ and $(3$, $2_{2}$ ). The defection of the 3 -vote member would be critical in both these coalitions as well as in the coalition $\left(3,2_{1}, 2_{2}\right)$. Hence, the Banzhaf power values of the voting body $(3,2,2)$ under a decision rule of 5 out of 7 are $(3 / 5,1 / 5,1 / 5)$, and the Coleman power values are $(1,1 / 3,1 / 3)$. 
Comparing these values with the corresponding Banzhaf $(5 / 12,1 / 4,1 / 4,1 / 12)$ and Coleman $(5 / 6,1 / 2,1 / 2,1 / 6)$ power values in the enlarged voting body $(3,2,2$, $1)$, we see that each of the two 2 -vote members increases its voting power from $1 / 5=0.2$ to $1 / 4=0.25$ by the Banzhaf index, and from $1 / 3=0.33$ to $1 / 2=0.5$ by the Coleman index. Thus, when the decision rule is the same in the original and enlarged bodies (5 votes), each of the 2-vote members - rather than 3-vote members benefits from addition of a 1-vote member to the original body.

The simultaneous decrease in a member's proportion of votes in the enlarged voting body, and his increase in voting power, is certainly paradoxical, especially since the new 1-vote member added to the voting body is not a dummy and - by its presence - deprives the other members together of some voting power. Under the decision rule of simple majority in the original and enlarged voting bodies, for example, it reduces the combined voting power of three original members from total of 1.0 to a total of 0.92 by the Banzhaf index, from a total of 2.0 to a total of 1.83 by the Coleman index. Despite this collective reduction in voting power of the three original members, however, the new member causes a redistribution in the share that remains so that the largest original member (3) benefits under simple majority rule.

There is a paradox of new members when one or more new members are added to a weighted voting body - with or without a change in the decision rule - and the voting power of one or more of the original members increases, rather than decreases. Although other paradoxes connected with the measurement of voting power have been identified, the paradox of new members is probably the one of greatest empirical interest. It is useful to distinguish three patterns associated with its occurrence: one or more dummies are empowered; one or more other members, excluding the largest are advantaged; the largest member enhances his dominant position.

\section{3 A Practical Example}

Conventional political wisdom suggests that a stratagem for diluting the power of the dominant member (or coalition) in a voting body is to increase the size of the body (see Brams, 1976). The are numerous examples of this maneuvre's being employed, ranging from Franklin Roosevelt's (unsuccessful) attempt to pack the Supreme Court in the 1930s to (successful) efforts by Democrats in the U.S. House of Representatives to enlarge the membership of the Rules Committee in the 1960s and 1970 s in the $20^{\text {th }}$ century.

Part of the rationale behind this sort of maneuvre is usually the conviction that the new members will be positioned ideologically and behaviourally in opposition to the previously dominant faction - that is, they will join only certain coalitions. There are cases, however, when a voting power of a previous member in a community increased, in spite of the enlargement of the community. This phenomenon is called the paradox of new members.

The American Constitution, for example, provides for election of a president by electors from each state equal to its number of senators and representatives. Although there is no provision in the Constitution that the electors from each state must vote as a bloc, in fact since the beginning of the republic the states, in an apparent effort to maximize their voting power, have almost invariably cast their votes as blocks. This feature of voting in the Electoral College is known as "unit rule".

Eleven times in its history the Electoral College has increased in size, while the original assigned weights of members remained intact. Normally, this was the result of the admission of a state or a set of states to the Union during the interval between decennial apportionments. In two of these eleven cases, the computation of the Banzhaf index (defined later) for the state showed up the occurrence of the para- 
dox of new members: once with the expansion of the Electoral College from 17 to 18 members in 1812, and a second time with its expansion to 19 members in 1816.

A more significant, if less pure, case of the paradox of new members occurred with the expansion of the European Community from six to nine members (see Taylor, 1995). In 1967 this international organization had as its governing body a Council of Ministers, representing the national viewpoints of its members. The numbers of votes of each country in the original Council, established by the Treaty of Rome in 1958, and the new Council, which replaced the old Council in 1973, are shown in Table 2.

Table 2

Banzhaf Index for Members of Council

\begin{tabular}{|l|c|c|c|c|}
\hline \multirow{2}{*}{} & \multicolumn{2}{|c|}{1958} & \multicolumn{2}{c|}{1973} \\
\cline { 2 - 5 } & Weight & Banzhaf index & Weight & Banzhaf index \\
\hline France & 4 & 0.238 & 10 & 0.167 \\
\hline Germany & 4 & 0.238 & 10 & 0.167 \\
\hline Italy & 4 & 0.238 & 10 & 0.167 \\
\hline Belgium & 2 & 0.143 & 5 & 0.091 \\
\hline Netherlands & 2 & 0.143 & 5 & 0.091 \\
\hline Luxembourg & 1 & 0.000 & 2 & 0.016 \\
\hline Denmark & - & - & 3 & 0.066 \\
\hline Ireland & - & - & 3 & 0.066 \\
\hline United Kingdom & - & - & 10 & 0.167 \\
\hline
\end{tabular}

Source: Taylor, 1995, p. 20.

It is clear that the admission of Denmark, Ireland, and the United Kingdom to membership in the European Community in 1973 diluted the voting power of all the members on the original Council except Luxembourg. It is astounding that Luxembourg exercised absolutely no influence on decisions of the original Council: the subtraction of its one vote could, under no circumstances, render a winning coalition losing, so its power according to the Banzhaf (as well as Coleman) index was necessarily zero.

When Luxembourg was given a second vote on the 1973 Council, its voting power increased to 0.02 by the Banzhaf index, which would seem to confirm the existence of a paradox of new members. Strictly speaking, however, this increase in Luxembourg's voting power on the new Council does not meet the conditions of the paradox illustrated earlier, because in the case of the Council, the weights of old members did change when new members were added. This was, therefore, an unclear paradox of new members. 


\section{Dat a}

Voting power indicators for the former and enlarged European Union were computed by Loužek (2004). These indices are: A. the simple relative power, B. the share in majority coalitions, $\mathrm{C}$. the Banzhaf index and D. the Coleman index. There were used nine algorithms, according to following situations:

a) structure of votes in the European Parliament (EP), simple majority and original EU (without enlargement);

b) structure of votes in the EP, enlarged EU, simple majority;

c) structure of votes in the Council, the EU without enlargement, simple majority of countries and representatives in the Council;

Table 3

The Relative Power (in \%)

\begin{tabular}{|c|c|c|c|c|c|c|c|c|c|}
\hline & Algor. 1 & Algor. 2 & Algor. 3 & Algor. 4 & Algor. 5 & Algor. 6 & Algor. 7 & Algor. 8 & Algor. 9 \\
\hline Germany & 18.50 & 13.52 & 12.24 & 8.40 & 8.40 & 15.37 & 9.66 & 18.26 & 17.61 \\
\hline Un. Kingdom & 13.46 & 9.83 & 12.24 & 8.40 & 8.40 & 11.18 & 9.66 & 13.28 & 12.81 \\
\hline France & 13.46 & 9.83 & 12.24 & 8.40 & 8.40 & 11.18 & 9.66 & 13.28 & 12.81 \\
\hline Italy & 13.46 & 9.83 & 12.24 & 8.40 & 8.40 & 11.18 & 9.66 & 13.28 & 12.81 \\
\hline Spain & 9.35 & 6.83 & 11.39 & 7.82 & 7.82 & 7.76 & 9 & 9.22 & 8.89 \\
\hline Netherlands & 4.67 & 3.41 & 5.49 & 3.76 & 3.76 & 3.88 & 4.33 & 4.61 & 4.44 \\
\hline Greece & 4.11 & 3.01 & 5.06 & 3.47 & 3.47 & 3.41 & 4 & 4.05 & 3.91 \\
\hline Belgium & 4.11 & 3.01 & 5.06 & 3.47 & 3.47 & 3.41 & 4 & 4.05 & 3.91 \\
\hline Portugal & 4.11 & 3.01 & 5.06 & 3.47 & 3.47 & 3.41 & 4 & 4.05 & 3.91 \\
\hline Sweden & 3.36 & 2.46 & 4.22 & 2.89 & 2.89 & 2.79 & 3.33 & 3.32 & 3.20 \\
\hline Austria & 3.18 & 2.32 & 4.22 & 2.89 & 2.89 & 2.63 & 3.33 & 3.13 & 3.02 \\
\hline Denmark & 2.43 & 1.77 & 2.95 & 2.02 & 2.02 & 2.01 & 2.33 & 2.39 & 2.31 \\
\hline Finland & 2.43 & 1.77 & 2.95 & 2.02 & 2.02 & 2.01 & 2.33 & 2.39 & 2.31 \\
\hline Ireland & 2.24 & 1.63 & 2.95 & 2.02 & 2.02 & 1.86 & 2.33 & 2.21 & 2.13 \\
\hline Luxembourg & 1.12 & 0.81 & 1.69 & 1.15 & 1.15 & 0.93 & 1.33 & 1.10 & 1.06 \\
\hline Poland & 0 & 6.83 & 0 & 7.82 & 7.82 & 7.76 & 9 & 0 & 0 \\
\hline (Romania) & 0 & 4.51 & 0 & 4.05 & 4.05 & 0 & 0 & 0 & 0 \\
\hline $\begin{array}{l}\text { Czech } \\
\text { Republic }\end{array}$ & 0 & 2.73 & 0 & 3.47 & 3.47 & 3.10 & 4 & 0 & 0 \\
\hline Hungary & 0 & 2.73 & 0 & 3.47 & 3.47 & 3.10 & 4 & 0 & 3.55 \\
\hline (Bulgaria) & 0 & 2.32 & 0 & 2.89 & 2.89 & 0 & 0 & 0 & 0 \\
\hline Slovakia & 0 & 1.77 & 0 & 2.02 & 2.02 & 0 & 0 & 0 & 0 \\
\hline Lithuania & 0 & 1.63 & 0 & 2.02 & 2.02 & 0 & 0 & 0 & 0 \\
\hline Latvia & 0 & 1.09 & 0 & 1.15 & 1.15 & 0 & 0 & 0 & 0 \\
\hline Slovenia & 0 & 0.95 & 0 & 1.15 & 1.15 & 1.08 & 1.33 & 1.29 & 1.24 \\
\hline Estonia & 0 & 0.81 & 0 & 1.15 & 1.15 & 0.93 & 1.33 & 0 & 0 \\
\hline Cyprus & 0 & 0.81 & 0 & 1.15 & 1.15 & 0.93 & 1.33 & 0 & 0 \\
\hline Malta & 0 & 0.68 & 0 & 0.86 & 0.86 & 0 & 0 & 0 & 0 \\
\hline In total $(\%)$ & 100 & 100 & 100 & 100 & 100 & 100 & 100 & 100 & 100 \\
\hline Total votes & 535 & 732 & 237 & 345 & 345 & 644 & 300 & 542 & 562 \\
\hline
\end{tabular}


d) structure of votes in the Council, enlarged EU, simple majority of countries and representatives;

e) structure of votes in the Council, enlarged EU, qualified majority;

f) structure of votes in the EP, "partially enlarged" EU (Poland, the Czech Republic, Hungary, Slovenia, Estonia and Cyprus), simple majority;

g) structure of votes in the Council, partially enlarged EU (Poland, Hungary, the Czech Republic, Slovenia, Estonia, Cyprus, qualified majority);

h) structure of votes in the EP, "symbolically enlarged" EU (Slovenia), simple majority;

ch) structure of votes in the EP, "alternatively symbolically enlarged EU" (Hungary, Slovenia), simple majority.

Table 3 brings the relative power indices for all EU and candidate countries. All indices decrease if the EU enlargement comes into being. This is not surprising because the voting power, according to this index, "dilutes" during the process of the

Table 4

Shares in Majority Coalitions (in \%)

\begin{tabular}{|c|c|c|c|c|c|c|c|c|c|}
\hline & Algor. 1 & Algor. 2 & Algor. 3 & Algor. 4 & Algor. 5 & Algor. 6 & Algor. 7 & Algor. 8 & Algor. 9 \\
\hline Germany & 74.05 & 72.31 & 66.43 & 63.33 & 91.51 & 72.96 & 90.45 & 74.17 & 74.05 \\
\hline Un. Kingdom & 66.30 & 65.22 & 66.43 & 63.33 & 91.51 & 65.57 & 90.45 & 66.34 & 66.24 \\
\hline France & 66.30 & 65.22 & 66.43 & 63.33 & 91.51 & 65.57 & 90.45 & 66.34 & 66.24 \\
\hline Italy & 66.30 & 65.22 & 66.43 & 63.33 & 91.51 & 65.57 & 90.45 & 66.34 & 66.24 \\
\hline Spain & 61.66 & 60.31 & 65.67 & 62.73 & 89.70 & 60.51 & 88.54 & 61.63 & 61.41 \\
\hline Netherlands & 55.12 & 55.08 & 60.80 & 58.57 & 71.58 & 55.21 & 70.56 & 55.33 & 55.30 \\
\hline Greece & 54.64 & 54.47 & 60.31 & 58.30 & 70.03 & 54.57 & 69.02 & 54.64 & 54.68 \\
\hline Belgium & 54.64 & 54.47 & 60.31 & 58.30 & 70.03 & 54.57 & 69.02 & 54.64 & 54.68 \\
\hline Portugal & 54.64 & 54.47 & 60.31 & 58.30 & 70.03 & 54.57 & 69.02 & 54.64 & 54.68 \\
\hline Sweden & 53.73 & 53.65 & 59.71 & 57.76 & 66.85 & 53.74 & 65.87 & 53.83 & 53.82 \\
\hline Austria & 53.51 & 53.45 & 59.71 & 57.76 & 66.85 & 53.53 & 65.87 & 53.56 & 53.59 \\
\hline Denmark & 52.73 & 52.63 & 58.57 & 56.93 & 61.91 & 52.70 & 61.34 & 52.75 & 52.76 \\
\hline Finland & 52.73 & 52.63 & 58.57 & 56.93 & 61.91 & 52.70 & 61.34 & 52.75 & 52.76 \\
\hline Ireland & 52.55 & 52.43 & 58.57 & 56.93 & 61.91 & 52.49 & 61.34 & 52.55 & 52.54 \\
\hline Luxembourg & 51.14 & 51.21 & 57.60 & 56.12 & 56.87 & 51.24 & 56.51 & 51.28 & 51.30 \\
\hline Poland & 0 & 60.31 & 0 & 62.73 & 89.70 & 60.51 & 88.54 & 0 & 0 \\
\hline (Romania) & 0 & 56.74 & 0 & 58.84 & 73.17 & 0 & 0 & 0 & 0 \\
\hline $\begin{array}{l}\text { Czech } \\
\text { Republic }\end{array}$ & 0 & 54.06 & 0 & 58.30 & 70.03 & 54.16 & 69.02 & 0 & 0 \\
\hline Hungary & 0 & 54.06 & 0 & 58.30 & 70.03 & 54.16 & 69.02 & 0 & 54.24 \\
\hline (Bulgaria) & 0 & 53.45 & 0 & 57.76 & 66.85 & 0 & 0 & 0 & 0 \\
\hline Slovakia & 0 & 52.63 & 0 & 56.93 & 61.91 & 0 & 0 & 0 & 0 \\
\hline Lithuania & 0 & 52.43 & 0 & 56.93 & 61.91 & 0 & 0 & 0 & 0 \\
\hline Latvia & 0 & 51.62 & 0 & 56.12 & 56.87 & 0 & 0 & 0 & 0 \\
\hline Slovenia & 0 & 51.417 & 0 & 56.12 & 56.87 & 51.45 & 56.51 & 51.47 & 51.47 \\
\hline Estonia & 0 & 51.21 & 0 & 56.12 & 56.87 & 51.24 & 56.51 & 0 & 0 \\
\hline Cyprus & 0 & 51.21 & 0 & 56.12 & 56.87 & 51.24 & 56.51 & 0 & 0 \\
\hline Malta & 0 & 51.01 & 0 & 55.84 & 55.13 & 0 & 0 & 0 & 0 \\
\hline$M C^{1)}$ & 16384 & 66837454 & 13511 & 55475483 & 2080525 & 1044204 & 54486 & 32624 & 65236 \\
\hline
\end{tabular}

1) Majority coalitions. 
enlargement. The bigger enlargement, the stronger is the difference between original and new relative power. The smallest differences are by symbolically enlarged and alternatively symbolically enlarged European Parliament.

Table 4 specifies the shares of individual countries in majority coalitions. We see that all the indices have biases toward $50 \%$, because there is approximately the same probability that a country in question is in majority coalition or not. Bigger countries have higher indices, for they are more important for majority coalitions.

Table 5

Banzhaf Indices (in \%)

\begin{tabular}{|c|c|c|c|c|c|c|c|c|c|}
\hline & Algor. 1 & Algor. 2 & Algor. 3 & Algor. 4 & Algor. 5 & Algor. 6 & Algor. 7 & Algor. 8 & Algor. 9 \\
\hline Germany & 20.03 & 15.00 & 12.78 & 8.55 & 8.07 & 16.99 & 9.42 & 20.17 & 19.51 \\
\hline Un. Kingdom & 13.58 & 10.19 & 12.78 & 8.55 & 8.07 & 11.47 & 9.42 & 13.58 & 13.11 \\
\hline France & 13.58 & 10.19 & 12.78 & 8.55 & 8.07 & 11.47 & 9.42 & 13.58 & 13.11 \\
\hline Italy & 13.58 & 10.19 & 12.78 & 8.55 & 8.07 & 11.47 & 9.42 & 13.58 & 13.11 \\
\hline Spain & 9.71 & 6.86 & 11.83 & 7.90 & 7.71 & 7.69 & 8.96 & 9.61 & 9.16 \\
\hline Netherlands & 4.27 & 3.31 & 5.40 & 3.73 & 4.02 & 3.73 & 4.58 & 4.30 & 4.15 \\
\hline Greece & 3.87 & 2.89 & 4.79 & 3.44 & 3.71 & 3.26 & 4.22 & 3.72 & 3.64 \\
\hline Belgium & 3.87 & 2.89 & 4.79 & 3.44 & 3.71 & 3.26 & 4.22 & 3.72 & 3.64 \\
\hline Portugal & 3.87 & 2.89 & 4.79 & 3.44 & 3.71 & 3.26 & 4.22 & 3.72 & 3.64 \\
\hline Sweden & 3.11 & 2.34 & 4.03 & 2.87 & 3.06 & 2.64 & 3.47 & 3.04 & 2.94 \\
\hline Austria & 2.92 & 2.20 & 4.03 & 2.87 & 3.06 & 2.48 & 3.47 & 2.82 & 2.76 \\
\hline Denmark & 2.27 & 1.65 & 2.64 & 2.01 & 2.06 & 1.86 & 2.34 & 2.13 & 2.07 \\
\hline Finland & 2.27 & 1.65 & 2.64 & 2.01 & 2.06 & 1.86 & 2.34 & 2.13 & 2.07 \\
\hline Ireland & 2.12 & 1.51 & 2.64 & 2.01 & 2.06 & 1.70 & 2.34 & 1.96 & 1.89 \\
\hline Luxembourg & 0.95 & 0.69 & 1.32 & 1.15 & 1.04 & 0.77 & 1.19 & 0.89 & 0.88 \\
\hline Poland & 0 & 6.86 & 0 & 7.90 & 7.71 & 7.69 & 8.96 & 0 & 0 \\
\hline (Romania) & 0 & 4.43 & 0 & 4.02 & 4.34 & 0 & 0 & 0 & 0 \\
\hline $\begin{array}{l}\text { Czech } \\
\text { Republic }\end{array}$ & 0 & 2.62 & 0 & 3.44 & 3.71 & 2.95 & 4.22 & 0 & 0 \\
\hline Hungary & 0 & 2.62 & 0 & 3.44 & 3.71 & 2.95 & 4.22 & 0 & 3.28 \\
\hline (Bulgaria) & 0 & 2.20 & 0 & 2.87 & 3.06 & 0 & 0 & 0 & 0 \\
\hline Slovakia & 0 & 1.65 & 0 & 2.01 & 2.06 & 0 & 0 & 0 & 0 \\
\hline Lithuania & 0 & 1.51 & 0 & 2.01 & 2.06 & 0 & 0 & 0 & 0 \\
\hline Latvia & 0 & 0.96 & 0 & 1.15 & 1.04 & 0 & 0 & 0 & 0 \\
\hline Slovenia & 0 & 0.82 & 0 & 1.15 & 1.04 & 0.93 & 1.19 & 1.06 & 1.02 \\
\hline Estonia & 0 & 0.69 & 0 & 1.15 & 1.04 & 0.77 & 1.19 & 0 & 0 \\
\hline Cyprus & 0 & 0.69 & 0 & 1.15 & 1.04 & 0.77 & 1.19 & 0 & 0 \\
\hline Malta & 0 & 0.55 & 0 & 0.86 & 0.69 & 0 & 0 & 0 & 0 \\
\hline$\sum B I_{i}(\%)$ & 100 & 100 & 100 & 100 & 100 & 100 & 100 & 100 & 100 \\
\hline$\sum B M_{i}($ abs. $)$ & 39342 & $1.97 \times 10^{08}$ & 28493 & $1.38 \times 10^{08}$ & 21156211 & 2796428 & 462149 & 77460 & 159310 \\
\hline
\end{tabular}

Also Banzhaf indices increase with the size of a country. It is considerable, however, that Banzhaf indices differ from the simple relative power: Banzhaf index reinforces the voting power of bigger countries and weakens the one of smaller coun- 
tries. At most Banzhaf indices decrease when EU enlargement occurs. Similar patterns govern also Coleman indices, which describes Table 6.

Table 6

Coleman indices (in \%)

\begin{tabular}{|c|c|c|c|c|c|c|c|c|c|}
\hline & Algor. 1 & Algor. 2 & Algor. 3 & Algor. 4 & Algor. 5 & Algor. 6 & Algor. 7 & Algor. 8 & Algor. 9 \\
\hline Germany & 69.58 & 68.20 & 54.78 & 51.04 & 90.81 & 68.77 & 89.50 & 69.71 & 69.65 \\
\hline Un. Kingdom & 47.16 & 46.34 & 54.78 & 51.04 & 90.81 & 46.44 & 89.50 & 46.93 & 46.82 \\
\hline France & 47.16 & 46.34 & 54.78 & 51.04 & 90.81 & 46.44 & 89.50 & 46.93 & 46.82 \\
\hline Italy & 47.16 & 46.34 & 54.78 & 51.04 & 90.81 & 46.44 & 89.50 & 46.93 & 46.82 \\
\hline Spain & 33.74 & 31.18 & 50.73 & 47.20 & 86.66 & 31.14 & 85.14 & 33.21 & 32.70 \\
\hline Netherlands & 14.81 & 15.05 & 23.16 & 22.27 & 45.22 & 15.11 & 43.53 & 14.87 & 14.82 \\
\hline Greece & 13.44 & 13.15 & 20.54 & 20.55 & 41.72 & 13.20 & 40.04 & 12.86 & 13.01 \\
\hline Belgium & 13.44 & 13.15 & 20.54 & 20.55 & 41.72 & 13.20 & 40.04 & 12.86 & 13.01 \\
\hline Portugal & 13.44 & 13.15 & 20.54 & 20.55 & 41.72 & 13.20 & 40.04 & 12.86 & 13.01 \\
\hline Sweden & 10.79 & 10.64 & 17.29 & 17.12 & 34.43 & 10.67 & 32.94 & 10.49 & 10.51 \\
\hline Austria & 10.15 & 10.01 & 17.29 & 17.12 & 34.43 & 10.05 & 32.94 & 9.74 & 9.84 \\
\hline Denmark & 7.89 & 7.50 & 11.30 & 12.00 & 23.19 & 7.52 & 22.20 & 7.37 & 7.39 \\
\hline Finland & 7.89 & 7.50 & 11.30 & 12.00 & 23.19 & 7.52 & 22.20 & 7.37 & 7.39 \\
\hline Ireland & 7.36 & 6.87 & 11.30 & 12.00 & 23.19 & 6.89 & 22.20 & 6.77 & 6.76 \\
\hline Luxembourg & 3.30 & 3.12 & 5.67 & 6.89 & 11.68 & 3.13 & 11.33 & 3.07 & 3.14 \\
\hline Poland & 0 & 31.18 & 0 & 47.20 & 86.66 & 31.14 & 85.14 & 0 & 0 \\
\hline (Romania) & 0 & 20.16 & 0 & 24.02 & 48.79 & 0 & 0 & 0 & 0 \\
\hline $\begin{array}{l}\text { Czech } \\
\text { Republic }\end{array}$ & 0 & 11.89 & 0 & 20.55 & 41.72 & 11.94 & 40.04 & 0 & 0 \\
\hline Hungary & 0 & 11.89 & 0 & 20.55 & 41.72 & 11.94 & 40.04 & 0 & 11.72 \\
\hline (Bulgaria) & 0 & 10.01 & 0 & 17.12 & 34.43 & 0 & 0 & 0 & 0 \\
\hline Slovakia & 0 & 7.50 & 0 & 12.00 & 23.19 & 0 & 0 & 0 & 0 \\
\hline Lithuania & 0 & 6.87 & 0 & 12.00 & 23.19 & 0 & 0 & 0 & 0 \\
\hline Latvia & 0 & 4.37 & 0 & 6.89 & 11.68 & 0 & 0 & 0 & 0 \\
\hline Slovenia & 0 & 3.75 & 0 & 6.89 & 11.68 & 3.76 & 11.33 & 3.65 & 3.64 \\
\hline Estonia & 0 & 3.12 & 0 & 6.89 & 11.68 & 3.13 & 11.33 & 0 & 0 \\
\hline Cyprus & 0 & 3.12 & 0 & 6.89 & 11.68 & 3.13 & 11.33 & 0 & 0 \\
\hline Malta & 0 & 2.50 & 0 & 5.16 & 7.81 & 0 & 0 & 0 & 0 \\
\hline$M W C^{11}$ & 11328 & 43330354 & 6645 & 23107924 & 1881096 & 690912 & 48657 & 22412 & 44622 \\
\hline
\end{tabular}

1) Minimal winning coalitions.

\section{Differences between Old and New Voting Power Indicators}

To find out, whether the paradox of new members comes into being during the EU-enlargement, I have computed differences between old and new voting power indicators. There are many cases when the share of a country in (minimal) winning 
coalitions increases, in spite of the enlargement of the European Union. At most this happens by the share of countries in minimal winning coalitions, then by the Coleman index and at the least by the Banzhaf index. At first, I want to verify that the paradox of new members cannot come into being by the simple relative power $(R)$.

A. Simple Relative Power. All differences of the former and following simple relative power after the EU enlargement are negative, e.g. the simple relative power decreases after EU enlargement. The relative power is the only voting indicator, by which no paradox occurs, even in unclear form, which indicates column $R_{7}-R_{3}$.

Table 7

Differences in Simple Relative Powers according to Different Variants of EU Enlargement $(\Delta R)$

\begin{tabular}{|l|c|c|c|c|c|c|}
\hline & $\begin{array}{c}\text { Complete } \\
\text { enlarge- } \\
\text { ment, EP }\end{array}$ & $\begin{array}{c}\text { Complete } \\
\text { enlarge- } \\
\text { ment, } \\
\text { Council }\end{array}$ & $\begin{array}{c}\text { Partial } \\
\text { enlarge- } \\
\text { ment, EP }\end{array}$ & $\begin{array}{c}\text { Partial } \\
\text { enlarge- } \\
\text { ment, Coun- } \\
\text { cil, qualified } \\
\text { majority }\end{array}$ & $\begin{array}{c}\text { Symbolic } \\
\text { enlarge- } \\
\text { ment, EP }\end{array}$ & $\begin{array}{c}\text { Otherwise } \\
\text { symbolic } \\
\text { enlarge- } \\
\text { ment, EP }\end{array}$ \\
\cline { 2 - 7 } & $R_{2}-R_{1}$ & $R_{4}-R_{3}$ & $R_{6}-R_{1}$ & $R_{7}-R_{3}$ & $R_{8}-R_{1}$ & $R_{9}-R_{1}$ \\
\hline Germany & -4.98 & -3.80 & -3.13 & -2.54 & -0.24 & -0.89 \\
\hline United Kingdom & -3.63 & -3.80 & -2.28 & -2.54 & -0.18 & -0.65 \\
\hline France & -3.63 & -3.80 & -2.28 & -2.54 & -0.18 & -0.65 \\
\hline Italy & -3.63 & -3.80 & -2.28 & -2.54 & -0.18 & -0.65 \\
\hline Spain & -2.52 & -3.58 & -1.59 & -2.40 & -0.13 & -0.46 \\
\hline Netherlands & -1.26 & -1.74 & -0.79 & -1.17 & -0.06 & -0.23 \\
\hline Greece & -1.10 & -1.63 & -0.70 & -1.10 & -0.06 & -0.20 \\
\hline Belgium & -1.10 & -1.63 & -0.70 & -1.10 & -0.06 & -0.20 \\
\hline Portugal & -1.10 & -1.63 & -0.70 & -1.10 & -0.06 & -0.20 \\
\hline Sweden & -0.90 & -1.31 & -0.57 & -0.87 & -0.04 & -0.16 \\
\hline Austria & -0.86 & -1.31 & -0.55 & -0.87 & -0.05 & -0.16 \\
\hline Denmark & -0.66 & -0.98 & -0.42 & -0.67 & -0.04 & -0.12 \\
\hline Finland & -0.66 & -0.98 & -0.42 & -0.67 & -0.04 & -0.12 \\
\hline Ireland & -0.61 & -0.98 & -0.38 & -0.67 & -0.03 & -0.11 \\
\hline Luxembourg & -0.31 & -0.55 & -0.19 & -0.37 & -0.02 & -0.06 \\
\hline
\end{tabular}

The "biggest" differences (in absolute value) come into being during the complete enlargement of the European Parliament. The less ambitious enlargement of the European Parliament (last two columns), the smaller differences appear to be. Significant negative differences shows the enlargement of the Council. During the enlargement of the Council with a change of decision rule, differences are also negative, although being in absolute value smaller than by the simple enlargement without the change of voting power. 
B. Shares in Majority Coalitions. For shares of countries in majority coalitions, the paradox of new members comes into being relatively often (see Table 8). Luxembourg increases its share in majority coalitions by the enlargement of the European Parliament, although only slightly. During the enlargement of the Council, no paradox of new members occurs. Significant increasing of the shares comes into being during the enlargement of the Council with a new qualified majority (algorithm 5). This is not, however, the paradox of new members in "clear" form.

Table 8

Differences in Shares in Majority Coalitions according to Different Variants of the EU Enlargement $(\triangle S M)$

\begin{tabular}{|l|c|c|c|c|c|c|}
\hline & $\begin{array}{c}\text { Complete } \\
\text { enlarge- } \\
\text { ment, EP }\end{array}$ & $\begin{array}{c}\text { Complete } \\
\text { enlarge- } \\
\text { ment, } \\
\text { Council }\end{array}$ & $\begin{array}{c}\text { Partial } \\
\text { enlarge- } \\
\text { ment, EP }\end{array}$ & $\begin{array}{c}\text { Partial } \\
\text { enlarge- } \\
\text { ment, Coun- } \\
\text { cil, qualified } \\
\text { majority }\end{array}$ & $\begin{array}{c}\text { Symbolic } \\
\text { enlarge- } \\
\text { ment, EP }\end{array}$ & $\begin{array}{c}\text { Otherwise } \\
\text { symbolic } \\
\text { enlarge- } \\
\text { ment, EP }\end{array}$ \\
\cline { 2 - 7 } & $S M_{2}-S M_{1}$ & $S M_{4}-S M_{3}$ & $S M_{6}-S M_{1}$ & $S M_{7}-S M_{3}$ & $S M_{8}-S M_{1}$ & $S M_{9}-S M_{1}$ \\
\hline Germany & -1.74 & -3.10 & -1.09 & 24.02 & $\mathbf{0 . 1 2}$ & 0 \\
\hline United Kingdom & -1.08 & -3.10 & -0.73 & 24.02 & $\mathbf{0 . 0 4}$ & -0.06 \\
\hline France & -1.08 & -3.10 & -0.73 & 24.02 & $\mathbf{0 . 0 4}$ & -0.06 \\
\hline Italy & -1.08 & -3.10 & -0.73 & 24.02 & $\mathbf{0 . 0 4}$ & -0.06 \\
\hline Spain & -1.35 & -2.94 & -1.15 & 22.87 & -0.03 & -0.25 \\
\hline Netherlands & -0.04 & -2.23 & $\mathbf{0 . 0 9}$ & 9.76 & $\mathbf{0 . 2 1}$ & $\mathbf{0 . 1 8}$ \\
\hline Greece & -0.17 & -2.01 & -0.07 & 8.71 & 0 & $\mathbf{0 . 0 4}$ \\
\hline Belgium & -0.17 & -2.01 & -0.07 & 8.71 & 0 & $\mathbf{0 . 0 4}$ \\
\hline Portugal & -0.17 & -2.01 & -0.07 & 8.71 & 0 & $\mathbf{0 . 0 4}$ \\
\hline Sweden & -0.08 & -1.95 & $\mathbf{0 . 0 1}$ & 6.16 & $\mathbf{0 . 1 0}$ & $\mathbf{0 . 0 9}$ \\
\hline Austria & -0.06 & -1.95 & $\mathbf{0 . 0 2}$ & 6.16 & $\mathbf{0 . 0 5}$ & $\mathbf{0 . 0 8}$ \\
\hline Denmark & -0.10 & -1.64 & -0.03 & 2.77 & $\mathbf{0 . 0 2}$ & $\mathbf{0 . 0 3}$ \\
\hline Finland & -0.10 & -1.64 & -0.03 & 2.77 & $\mathbf{0 . 0 2}$ & $\mathbf{0 . 0 3}$ \\
\hline Ireland & -0.12 & -1.64 & -0.06 & 2.77 & $\mathbf{0}$ & -0.01 \\
\hline Luxembourg & $\mathbf{0 . 0 7}$ & -1.48 & $\mathbf{0 . 1 0}$ & -1.09 & $\mathbf{0 . 1 4}$ & $\mathbf{0 . 1 6}$ \\
\hline
\end{tabular}

Several times the paradox of new members appears in partial enlargement of the European Parliament. In this case, the shares in majority coalitions are stronger for Netherlands, Sweden, Austria and Luxembourg. The most significant paradox of new members is by symbolically enlarged and otherwise symbolically enlarged European Parliament. In EU enlarged into Slovenia (algorithm 8), the shares in majority coalitions are stronger for Germany, United Kingdom, France, Italy, Netherlands, Sweden, Austria, Denmark, Finland and Luxembourg. In otherwise symbolically enlarged European Parliament (algorithm 9), the paradox of new members arises for Netherlands, Greece, Belgium, Portugal, Sweden, Austria, Denmark, Finland and Luxembourg. 
C. Banzhaf index. According to the Banzhaf index, the paradox of new members would occur in two cases - in symbolically enlarged European Parliament (into Slovenia) for Germany and Netherlands. In no other case, the Banzhaf index would be greater than it is today. This is not surprising because the sum of Banzhaf indices in column is one, which doesn't create too big room for the paradox in big voting bodies.

Table 9

Differences in Banzhaf Index according to Variants of EU Enlargement $(\Delta B I)$

\begin{tabular}{|l|c|c|c|c|c|c|}
\hline & $\begin{array}{c}\text { Complete } \\
\text { enlarge- } \\
\text { ment, EP }\end{array}$ & $\begin{array}{c}\text { Complete } \\
\text { enlarge- } \\
\text { ment, } \\
\text { Council }\end{array}$ & $\begin{array}{c}\text { Partial } \\
\text { enlarge- } \\
\text { ment, EP }\end{array}$ & $\begin{array}{c}\text { Partial } \\
\text { enlarge- } \\
\text { ment, Coun- } \\
\text { cil, qualified } \\
\text { majority }\end{array}$ & $\begin{array}{c}\text { Symbolic } \\
\text { enlarge- } \\
\text { ment, EP }\end{array}$ & $\begin{array}{c}\text { Otherwise } \\
\text { symbolic } \\
\text { enlarge- } \\
\text { ment, EP }\end{array}$ \\
\cline { 2 - 7 } & $B I_{2}-B I_{1}$ & $B I_{4}-B I_{3}$ & $B I_{6}-B I_{1}$ & $B I_{7}-B I_{3}$ & $B I_{8}-B I_{1}$ & $B I_{9}-B I_{1}$ \\
\hline Germany & -5.03 & -4.23 & -3.04 & -3.36 & 0.14 & -0.52 \\
\hline United Kingdom & -3.39 & -4.23 & -2.11 & -3.36 & 0 & -0.47 \\
\hline France & -3.39 & -4.23 & -2.11 & -3.36 & 0 & -0.47 \\
\hline Italy & -3.39 & -4.23 & -2.11 & -3.36 & 0 & -0.47 \\
\hline Spain & -2.85 & -3.93 & -2.02 & -2.87 & -0.10 & -0.55 \\
\hline Netherlands & -0.96 & -1.67 & -0.54 & -0.82 & 0.03 & -0.12 \\
\hline Greece & -0.98 & -1.35 & -0.61 & -0.57 & -0.15 & -0.23 \\
\hline Belgium & -0.98 & -1.35 & -0.61 & -0.57 & -0.15 & -0.23 \\
\hline Portugal & -0.98 & -1.35 & -0.61 & -0.57 & -0.15 & -0.23 \\
\hline Sweden & -0.77 & -1.16 & -0.47 & -0.56 & -0.07 & -0.17 \\
\hline Austria & -0.72 & -1.16 & -0.44 & -0.56 & -0.10 & -0.16 \\
\hline Denmark & -0.62 & -0.63 & -0.41 & -0.30 & -0.14 & -0.20 \\
\hline Finland & -0.62 & -0.63 & -0.41 & -0.30 & -0.14 & -0.20 \\
\hline Ireland & -0.61 & -0.63 & -0.42 & -0.30 & -0.16 & -0.23 \\
\hline Luxembourg & -0.26 & -0.17 & -0.18 & -0.13 & -0.06 & -0.07 \\
\hline
\end{tabular}

The "biggest" differences (in absolute value) have big countries - Germany, France, Italy and United Kingdom. There are significant negative differences in the enlargement of the Council. In three cases, the Banzhaf index has not changed in "symbolically enlarged" European Parliament - for France, Italy and United Kingdom.

D. Coleman index. The paradox of new members, according to Coleman index, comes into being relatively often. For most minimal winning coalitions the influence of previous members "dilutes" during the EU enlargement. There are situations, however, when the Coleman index increases. In the completely enlarged European Parliament, the Coleman index increases slightly for Netherlands, in the enlarged Council for Greece, Belgium, Portugal, Denmark, Finland, Ireland and Luxembourg. 
Table 10

Differences in Coleman Index according to Variants of EU Enlargement $(\Delta C /)$

\begin{tabular}{|l|c|c|c|c|c|c|}
\hline & $\begin{array}{c}\text { Complete } \\
\text { enlarge- } \\
\text { ment, EP }\end{array}$ & $\begin{array}{c}\text { Complete } \\
\text { enlarge- } \\
\text { ment, } \\
\text { Council }\end{array}$ & $\begin{array}{c}\text { Partial } \\
\text { enlarge- } \\
\text { ment, EP }\end{array}$ & $\begin{array}{c}\text { Partial } \\
\text { enlarge- } \\
\text { ment, Coun- } \\
\text { cil, qualified } \\
\text { majority }\end{array}$ & $\begin{array}{c}\text { Symbolic } \\
\text { enlarge- } \\
\text { ment, EP }\end{array}$ & $\begin{array}{c}\text { Otherwise } \\
\text { symbolic } \\
\text { enlarge- } \\
\text { ment, EP }\end{array}$ \\
\cline { 2 - 7 } & $\mathrm{Cl}_{2}-\mathrm{Cl}_{1}$ & $\mathrm{Cl}_{4}-\mathrm{Cl}_{3}$ & $\mathrm{Cl}_{6}-\mathrm{Cl}_{1}$ & $\mathrm{Cl}_{7}-\mathrm{Cl}_{3}$ & $\mathrm{Cl}_{8}-\mathrm{Cl}_{1}$ & $\mathrm{Cl_{9 } - \mathrm { Cl } _ { 1 }}$ \\
\hline Germany & -1.38 & -3.74 & -0.81 & 34.72 & $\mathbf{0 . 1 3}$ & $\mathbf{0 . 0 7}$ \\
\hline United Kingdom & -0.82 & -3.74 & -0.72 & 34.72 & -0.23 & -0.34 \\
\hline France & -0.82 & -3.74 & -0.72 & 34.72 & -0.23 & -0.34 \\
\hline Italy & -0.82 & -3.74 & -0.72 & 34.72 & -0.23 & -0.34 \\
\hline Spain & -2.56 & -3.53 & -2.60 & 34.41 & -0.53 & -1.04 \\
\hline Netherlands & $\mathbf{0 . 2 4}$ & -0.89 & $\mathbf{0 . 3 0}$ & 20.37 & $\mathbf{0 . 0 6}$ & $\mathbf{0 . 0 1}$ \\
\hline Greece & -0.29 & $\mathbf{0 . 0 1}$ & -0.24 & 19.50 & -0.58 & -0.43 \\
\hline Belgium & -0.29 & $\mathbf{0 . 0 1}$ & -0.24 & 19.50 & -0.58 & -0.43 \\
\hline Portugal & -0.29 & $\mathbf{0 . 0 1}$ & -0.24 & 19.50 & -0.58 & -0.43 \\
\hline Sweden & -0.15 & -0.17 & -0.12 & 15.65 & -0.30 & -0.28 \\
\hline Austria & -0.14 & -0.17 & -0.10 & 15.65 & -0.41 & -0.31 \\
\hline Denmark & -0.39 & $\mathbf{0 . 7 0}$ & -0.37 & 10.90 & -0.52 & -0.50 \\
\hline Finland & -0.39 & $\mathbf{0 . 7 0}$ & -0.37 & 10.90 & -0.52 & -0.50 \\
\hline Ireland & -0.49 & $\mathbf{0 . 7 0}$ & -0.47 & 10.90 & -0.59 & -0.60 \\
\hline Luxembourg & -0.18 & $\mathbf{1 . 2 2}$ & -0.17 & 5.66 & -0.23 & -0.16 \\
\hline
\end{tabular}

In the "partially enlarged" European Parliament the paradox of new members arises for Netherlands, in "symbolically enlarged" and "otherwise symbolically enlarged" European Parliament for Germany and Netherlands. In less clear form there is the paradox of new members in algorithms 5 and 7 - thanks to the change in decision rule. All countries increase their shares in minimal winning coalitions, because of the rule of qualified majority of countries and votes. This phenomenon is similar for the Banzhaf index and the share in majority coalitions.

\section{The Frequency of the Paradox of New Members in Total}

The first hypothesis, which will be tested, is that the frequency of the paradox of new members is bigger for a share in majority coalitions than for the other voting power indicators. Table 11 confirms this hypothesis. According to shares of countries in majority coalitions, the paradox of new members comes into being in 24 cases, which are three fifths of all cases of the paradox. According to Coleman index, the clear paradox of new members occurs in thirteen cases, which is one fifth of all cases. Banzhaf index marks the paradox of new members only in two cases. 
Table 11

Paradox of New Members - the Frequency in Total

\begin{tabular}{|l|c|c|c|c|}
\hline & \multicolumn{2}{|c|}{ "Clear" paradox of new members } & "Unclear" paradox of new members \\
\cline { 2 - 5 } & Absolutely & Relatively (in \%) & Absolutely & Relatively (in \%) \\
\hline Relative power $(R)$ & 0 & 0 & 0 & 0 \\
\hline $\begin{array}{l}\text { The share in majority } \\
\text { coalitions }(S M)\end{array}$ & 24 & 61.6 & 14 & 48.3 \\
\hline Banzhaf index $(B I)$ & 2 & 5.1 & 0 & 0 \\
\hline Coleman index $(C l)$ & 13 & 33.3 & 15 & 51.7 \\
\hline Total & 39 & 100.0 & 29 & 100.0 \\
\hline
\end{tabular}

The frequency of the "unclear" paradox of new members in 29 cases is not surprising. This concerns fifteen cases of increasing Coleman index in the Council because of the change of voting rule and fourteen cases of the increasing share in majority coalitions (except of Luxembourg) in the same situation. Empirical results confirms the hypothesis that one cannot rule out the paradox of new members by the share in majority coalitions, Banzhaf index and Coleman index, while the paradox is not possible by the simple relative power.

The second hypothesis, which was stated by some authors (see Brams, 1976), is that the probability of the paradox of new members is higher for bigger countries than for smaller ones. The public choice literature says that if one member of a community dominates the others, its coalition power doesn't have to decrease during the

Table 12

Paradox of New Members - the Frequency according to Countries

\begin{tabular}{|l|c|c|c|c|}
\hline \multirow{2}{*}{} & \multicolumn{3}{|c|}{ "Clear" paradox of new members } & "Unclear" paradox of new members \\
\cline { 2 - 5 } & Absolutely & Relatively (in \%) & Absolutely & Relatively (in \%) \\
\hline Germany & 4 & 10.3 & 2 & 6.9 \\
\hline United Kingdom & 1 & 2.6 & 2 & 6.9 \\
\hline France & 1 & 2.6 & 2 & 6.9 \\
\hline Italy & 1 & 2.6 & 2 & 6.9 \\
\hline Spain & 0 & 0.0 & 2 & 6.9 \\
\hline Netherlands & 8 & 20.5 & 2 & 6.9 \\
\hline Greece & 2 & 5.1 & 2 & 6.9 \\
\hline Belgium & 2 & 5.1 & 2 & 6.9 \\
\hline Portugal & 2 & 5.1 & 2 & 6.9 \\
\hline Sweden & 3 & 7.7 & 2 & 6.9 \\
\hline Austria & 3 & 7.7 & 2 & 6.9 \\
\hline Denmark & 3 & 7.7 & 2 & 6.9 \\
\hline Finland & 3 & 7.7 & 2 & 6.9 \\
\hline Ireland & 1 & 2.6 & 2 & 6.9 \\
\hline Luxembourg & 5 & 12.8 & 1 & 3.4 \\
\hline Total & 39 & 100.0 & 29 & 100.0 \\
\hline
\end{tabular}


enlargement of the community, but it can even increase (during the EU enlargement Germany is a suspicious candidate).

Table 12 doesn't confirm that the paradox of new members has to appear more often for bigger countries than for smaller ones. At most the paradox is marked by Luxembourg and Netherlands, which are small states. Germany shows four cases, which is about one more than Sweden, Austria and Denmark. No paradox of new members occurs for Spain, one paradox for the United Kingdom, France and Italy. According to the frequency of the paradox, it does not seem that especially big countries would "earn" thanks to the EU enlargement.

\section{Conclusion}

There are two main types of the paradox of new members: "clear" one and "unclear" one. The clear paradox of new members means that during the enlargement of a community one of previous members increases its voting power, without changing a decision rule. The unclear paradox of new members means that the voting power of a member increases, while being changed the decision rule (f.e. transforming simple majority to qualified one).

To find out whether the paradox of new members comes into being during the EU enlargement, I have computed differences between the old and new voting power indicators before and after EU enlargement: the simple relative power, the share of countries in majority coalitions, the Banzhaf index and the Coleman index. Except for relative power, all voting indicators show the paradox of new members, at most the share of countries in majority coalitions, then Coleman index and then Banzhaf index.

At most often the paradox of new members appears in the share of countries in majority coalitions - in 24 cases in total, which are three fifths of all paradox cases. According to Coleman index, the clear paradox of new members comes into being in thirteen cases, which represents one third of all cases. Banzhaf index shows the paradox of new members only in two cases (5\% cases). The frequency of "unclear" paradox during the enlargement of the Council -29 cases - is not surprising.

Empirical results confirm the hypothesis that one can't rule out the paradox of new members by the share in majority coalitions, Banzhaf index and Coleman index, while the paradox can't come into being for the simple relative power. The hypothesis that the probability of the paradox is higher for bigger states than for smaller ones has not been confirmed.

References

Alker, H. J. Jr. (1965), Mathematics and Politics. New York, London: The Macmillan Company, Collier, Macmillan Limited.

Banzhaf, J. F. (1965), "Weighted Voting doesn't Work: a Mathematical Analysis." Rutgers Law Review, 19, pp. 317-343.

Brams, S. J. (1976), Paradoxes in Politics. An Introduction to the Non-obvious in Political Science. New York, London: The Free Press.

Buchanan, J. M., Tollison, R. D. (eds.) (1972), Theory of Public Choice. Political Applications of Economics. Ann Arbor: University of Michigan Press.

Coleman, J. S. (1971), "Control of Collectivities and the Power of a Collectivity to Act," in Liberman, B., ed., Social Choice. New York: Edvard Elgar, pp. 277-287.

Deagan, J., Packel, E. W. (1978), "A New Index of Power for Simple n-Person Games." International Journal of Game Theory, 7, pp. 113-123. 
Deutsch, K. W., Alker, H. R. Jr., Stoetzel, A. H. (eds.) (1973), Mathematical Approaches to Politics. Amsterdam, London, New York: Elsevier Scientific Publishing Company.

Dubey, P., Shapley, L. (1979), "Mathematical Properties of the Banzhaf Power Index." Mathematics of Operations Research, 4, pp. 99-131.

Dummett, M. (1984), Voting Procedures. Oxford: Clarendon Press.

Frexas, J., Gambarelli, G. (1997), "Common Internal Properties Among Power Indices." Control and Cybernetics, 26, pp. 591-604.

Garrett, G., Tsebelis, G. (1999), "Why Resist the Temptation to Apply Power Indices to the European Union." Journal of Theoretical Politics, 11, pp. 291-308.

Johnston, R. J. (1978), "On the Measurement of Power: Some Reaction to Laver." Environment and Planning, pp. 907-914.

Kilgour, D. M. (1974), "A Shapley Value for Cooperative Games with Quarrelling," in Rapoport, A., ed., Game Theory as a Theory of Conflict Resolution. Dordrecht-Holland: D. Reidel Publ. Comp., pp. 193-206.

Lane, J. E., Berg, S. (1999), "Relevance of Voting Power". Journal of Theoretical Politics, pp. 309320.

Laursen, F. (ed.) (1995), The Political Economy of European Integration. The Hague, Boston, London: Kluwer Law International.

Lewin, L., Vedung, E. (eds.) (1980), Politics as Rational Action. Essays in Public Choice and Policy Analysis. London: Reidel.

Loužek, M. (2004), "Voting Power Indicators in the European Union" (in Czech). Politická ekonomie, 52(3), pp. 291-312.

Machover, M., Felsenthal, D. S. (1998), The Measurement of Voting Power. Cheltenham, UK, Northampton, MA: Edvard Elgar.

Nurmi, H. (1997), "On Power Indices and Minimal Winning Coalitions." Control and Cybernetics, 26, pp. 609-612.

Owen, G. (1982), "Modification of the Banzhaf-Coleman Index for Games with a Priori Unions," in Holler, M., ed., Power, Voting and Voting Power. Würzburg, Wien: Physica-Verlag, pp. 232-238.

Penrose, L. S. (1946), "The Elementary Statistics of Majority Voting". Journal of the Royal Statistical Society, pp. 53-57.

Shapley, L. S., Shubik, M. (1954), "A Method for Evaluating the Distribution of Power in a Committee System." American Political Science Review, 48, pp. 787-792.

Taylor, A. D. (1995), Mathematics and Politics. Strategy, Voting, Power and Proof. New York, Heidelberg, London, etc.: Springer.

Tullock, G. (1998), On Voting - a Public Choice Approach. Cheltenham: Edward Elgar.

Turnovec, F. (2000), "New Issues in Voting Power Analysis." Prague Economic Papers, 9(2), pp. 171186.

Wellington, K. (1947), Voting Procedures in International Political Organizations. New York: Columbia University Press.

Widgrén, M. (1995), "National Interests, EU Enlargement and Coalition Formation. Four Essays on National Influence in the EU." Helsinki, The Research Institute of the Finnish Economy. 